\title{
GROWTH AND MORPHOLOGICAL RESPONSES OF Handroanthus impetiginosus (Mart. ex DC.) Mattos SEEDLINGS TO NITROGEN FERTILIZATION
}

\author{
CRESCIMENTO E RESPOSTAS MORFOLÓGICAS DE MUDAS DE IPÊ-ROXO \\ Handroanthus impetiginosus (Mart. ex DC.) Mattos À ADUBAÇÃO NITROGENADA
}

\author{
Moadir de Sousa LEITE ${ }^{1}$; Rômulo Magno Oliveira de FREITAS ${ }^{2}$; Tiago de Sousa \\ LEITE $^{1}$; Jeferson Luiz Dallabona DOMBROSKI ${ }^{3}$; José Hermogenes dos SANTOS JUNIOR ${ }^{1}$ \\ 1. Graduando em Agronomia, Universidade Federal Rural do Semi-Árido, Mossoró, RN, Brasil. moadir@outlook.com; 2. Professor, \\ Doutor em Fitotecnia, Instituto Federal de Educação, Ciência e Tecnologia Baiano, Valença, BA, Brasil; 3. Professor, Doutor em \\ Ciências Biológicas, Universidade Federal Rural do Semi-Árido, Mossoró, RN, Brasil.
}

\begin{abstract}
The use of native tree species for restoration of degraded areas is often hindered by the lack of information about the nutritional requirements of seedlings at the nursery stage. Therefore, this study aimed to evaluate the growth and morphological responses of Handroanthus impetiginosus seedlings to mineral nitrogen fertilization. The experiment was carried out from July to October 2013 in a seedling nursery under 50\% shade cloth. Seeds were germinated for 15 days in low density polystyrene trays and then transplanted into 0.9-L polyethylene plastic bags. A complete randomized block design was used, with four replications and four plants per experimental unit. Treatments consisted of five nitrogen levels $\left(0,50,150,300\right.$ and $\left.450 \mathrm{mg} \mathrm{N} \mathrm{dm}^{-3}\right)$, using ammonium sulfate as the nitrogen source. Two months after transplanting, the following variables were assessed: leaf chlorophyll content; leaf area; specific leaf area; leaf area ratio; root, stem, leaf and total dry mass; shoot dry mass/root dry mass ratio; shoot height/shoot dry mass ratio; and Dickson quality index. Mineral nitrogen fertilization improved seedling growth by promoting higher results of the leaf chlorophyll content, leaf area and shoot dry mass production. Thus, fertilized seedlings significantly expanded their leaves and invested more in shoot growth, improving their hardiness and quality. The nitrogen level of $240 \mathrm{mg} \mathrm{dm}^{-3}$ was considered to be the most effective for production of $H$. impetiginosus seedlings.
\end{abstract}

KEYWORDS: Handroanthus impetiginosus. Native plants. Reforestation. Seedling production.

\section{INTRODUCTION}

Handroanthus impetiginosus (Mart. ex DC.) Mattos is a tree species commonly found in the Caatinga biome. Due to its ecological importance, this species has been used in the second phase of reforestation programs for recovery of degraded areas (MAIA, 2004). However, the use of native tree species for restoration of degraded areas is often hindered by the lack of information about the nutritional requirements of seedlings at the nursery stage (GONÇALVES et al., 2012).

The use of native tree species for reforestation or floristic recovery of degraded areas is of great importance for reducing environmental impact and conserving biodiversity. Nevertheless, the success in a reforestation program depends on good quality seedlings (CALDEIRA et al., 2008). This quality is often influenced by several factors, such as provenance of seeds, type of container, substrate and mineral nutrition (CRUZ et al., 2006; SOUSA et al., 2013).

According to Ceconi et al. (2007), the use of fertile substrates during seedling production is a requirement for obtaining good quality seedlings and well-formed adult plants. Thus, better field performance can be achieved by providing seedlings with a substrate rich in nutrients (CRUZ et al., 2006; MARQUES et al., 2006). Well-established seedlings have better development and higher survival rates, which reduce the need for replanting.

Inadequate substrate fertilization has been considered one of the factors responsible for loss of seedlings and high rates of plant mortality after transplanting to the field (TUCCI et al., 2009). Seedling mortality in degraded areas constitutes an obstacle to reforestation programs and is a consequence of nutrient deficiency. This is because degraded soils usually have low levels of nitrogen available to plants, which limits the growth of tree species (SOUSA et al., 2013). Consequently, substrate fertilization plays an important role in the quality of the seedlings that are produced as well as their establishment in the field (TUCCI et al., 2009).

Nitrogen $(\mathrm{N})$ is one of the nutrients essential for plant growth and development. The use of this macronutrient to fertilize forest tree seedlings is an effective way to increase production and reduce the nursery stage, making the process more efficient. Adequate nitrogen nutrition helps to improve many 
plant characteristics, such as leaf nutrient content (CRUZ et al., 2006). One of the many available sources of this nutrient is ammonium sulfate, which is an inorganic compound frequently used as agricultural fertilizer (MALAVOLTA; MORAIS, 2007).

Therefore, knowledge of efficient seedling fertilization becomes indispensable. Considering the benefits of nitrogen fertilization and the current lack of information on the nitrogen requirements of native tree species, this study aimed to evaluate the growth and morphological responses of $H$. impetiginosus seedlings to mineral nitrogen fertilization.

\section{MATERIAL AND METHODS}

The experiment was carried out from July to October 2013 at the Department of Plant Sciences of the Federal Rural University of the Semi-Arid (UFERSA) in Mossoró, Rio Grande do Norte (5'11'S, 37º $20^{\prime} \mathrm{W}, 18 \mathrm{~m}$ above sea level). A complete randomized block design was used, with four replications and four plants per experimental unit. Treatments consisted of five nitrogen levels $(0$, 50, 150, 300 and $450 \mathrm{mg} \mathrm{N} \mathrm{dm}^{-3}$ ), using ammonium sulfate as the nitrogen source.

Handroanthus impetiginosus seeds were collected from the eastern campus of UFERSA and afterward processed and selected at the Plant Research Center of the Department of Plant Sciences. Seeds were sown in low density polystyrene trays with 128 cells containing coconut fiber. Fifteen days after sowing, seedlings were transplanted into polyethylene plastic bags of $0.9-\mathrm{L}$ volume filled with topsoil of a red-yellow latosol (Table 1). Each experimental unit was irrigated daily with $200 \mathrm{~mL}$ of water.

Table 1. Physical and chemical properties of the soil utilized.

\begin{tabular}{|c|c|c|}
\hline Physical properties & Unity & Value \\
\hline Coarse sand & $\mathrm{kg} \mathrm{kg}^{-1}$ & 0.66 \\
\hline Fine sand & $\mathrm{kg} \mathrm{kg}^{-1}$ & 0.21 \\
\hline Total sand & $\mathrm{kg} \mathrm{kg}^{-1}$ & 0.87 \\
\hline Silt & $\mathrm{kg} \mathrm{kg}^{-1}$ & 0.09 \\
\hline Clay & $\mathrm{kg} \mathrm{kg}^{-1}$ & 0.04 \\
\hline Chemical properties & Unity & Value \\
\hline $\mathrm{pH}$ in $\mathrm{H}_{2} \mathrm{O}$ & & 8.28 \\
\hline Electrical conductivity & $\mathrm{dS} \mathrm{m}{ }^{-1}$ & 0.13 \\
\hline Organic matter & $\mathrm{g} \mathrm{kg}^{-1}$ & 11.36 \\
\hline Nitrogen $(\mathrm{N})$ & $\mathrm{g} \mathrm{kg}^{-1}$ & 0.35 \\
\hline Calcium $\left(\mathrm{Ca}^{2+}\right)$ & $\mathrm{cmol}_{\mathrm{c}} \mathrm{dm}^{-3}$ & 3.20 \\
\hline Magnesium $\left(\mathrm{Mg}^{2+}\right)$ & $\mathrm{cmol}_{\mathrm{c}} \mathrm{dm}^{-3}$ & 0.48 \\
\hline Potassium $\left(\mathrm{K}^{+}\right)$ & $\mathrm{mg} \mathrm{dm}^{-3}$ & 98.85 \\
\hline Sodium $\left(\mathrm{Na}^{+}\right)$ & $\mathrm{mg} \mathrm{dm}^{-3}$ & 95.00 \\
\hline Phosphorus (P) & $\mathrm{mg} \mathrm{dm}^{-3}$ & 25.80 \\
\hline Copper $(\mathrm{Cu})$ & $\mathrm{mg} \mathrm{dm}^{-3}$ & 0.06 \\
\hline Iron $(\mathrm{Fe})$ & $\mathrm{mg} \mathrm{dm}^{-3}$ & 2.20 \\
\hline Zinc (Zn) & $\mathrm{mg} \mathrm{dm}^{-3}$ & 3.63 \\
\hline Manganese (Mn) & $\mathrm{mg} \mathrm{dm}^{-3}$ & 11.30 \\
\hline
\end{tabular}

Seedlings were grown in a nursery under $50 \%$ shade cloth, average temperature of $28.6{ }^{\circ} \mathrm{C}$ and relative humidity of $61.3 \%$. Two months after transplanting, the response of $H$. impetiginosus to mineral nitrogen fertilization was assessed by the following variables: leaf chlorophyll content; leaf area; specific leaf area; leaf area ratio; root, stem, leaf and total dry mass; shoot dry mass/root dry mass ratio; shoot height/shoot dry mass ratio; and Dickson quality index.

Leaf chlorophyll content was measured using a portable chlorophyll content meter (CCM200, Opti-Sciences, USA). The leaf disk method
(SOUZA et al., 2012) was then used to estimate leaf area. For assessment of dry mass, two plants were collected from each experimental unit. They were then divided into roots, stem and leaves and placed into a dry oven at $65{ }^{\circ} \mathrm{C}$ for $96 \mathrm{~h}$. Lastly, the Dickson quality index was calculated as recommended by Dickson et al. (1960).

The data were tested by one-way analysis of variance (ANOVA) and means compared by the Ftest using Sisvar software, version 5.3 (FERREIRA, 2011). SigmaPlot software (version 11.0; Systat Software, Inc., San Jose, CA, USA) also was used for regression analysis of statistically significant 
differences $(p<0.01)$. The mathematical models were chosen based on the biological explanation as well as the significance of the mean squares and parameter estimates.

\section{RESULTS AND DISCUSSION}

The ANOVA showed significant effects of the nitrogen levels on all variables assessed $(p<$ 0.01 ), indicating that mineral nitrogen fertilization influences the growth and morphology of Handroanthus impetiginosus seedlings (Table 2).

Table 2. Mean squares for growth and morphological variables of Handroanthus impetiginosus seedlings under mineral nitrogen fertilization.

\begin{tabular}{|c|c|c|c|c|c|c|c|c|c|c|c|c|}
\hline \multirow{2}{*}{ Source } & \multirow{2}{*}{$\mathrm{DF}$} & \multicolumn{11}{|c|}{ Mean squares } \\
\hline & & LCC & LA & SLA & LAR & RDM & SDM & LDM & TDM & SRR & HSR & DQI \\
\hline Nitrogen & 4 & $237.40^{* *}$ & $178070.50 * *$ & $1056.65^{* *}$ & $2508.93 * *$ & $0.23 * *$ & $0.25 * *$ & $4.34 * *$ & $6.32 * *$ & $9.58 * *$ & $5.74 * *$ & $0.63 * *$ \\
\hline Residual & 12 & 13.52 & 19277.90 & 181.35 & 66.60 & 0.03 & 0.03 & 0.45 & 0.74 & 0.39 & 0.47 & 0.09 \\
\hline $\mathrm{CV}(\%)$ & - & 13.70 & 21.36 & 6.95 & 7.03 & 16.28 & 16.40 & 20.24 & 15.66 & 14.81 & 15.83 & 17.80 \\
\hline
\end{tabular}

**Significant at the 1\% level; LCC - Leaf chlorophyll content; LA - Leaf area; SLA - Specific leaf area; LAR - Leaf area ratio; RDM - Root dry mass; SDM - Stem dry mass; LDM - Leaf dry mass; TDM - Total dry mass; SRR - Shoot dry mass/root dry mass ratio; HSR - Shoot height/shoot dry mass ratio; DQI - Dickson quality index.

It was observed that the chlorophyll content in $H$. impetiginosus leaves is proportional to the availability of nitrogen in the substrate (Figure 1A). Each $50 \mathrm{~g}$ of this macronutrient added to the soil increased the amount of the aforementioned pigment by $10 \%$ in relation to control plants $\left(0 \mathrm{mg} \mathrm{N} \mathrm{dm}^{-3}\right)$. A linear positive correlation between leaf chlorophyll content and mineral nitrogen fertilization also was observed by Smarsi et al. (2011) for Litchi chinensis seedlings.
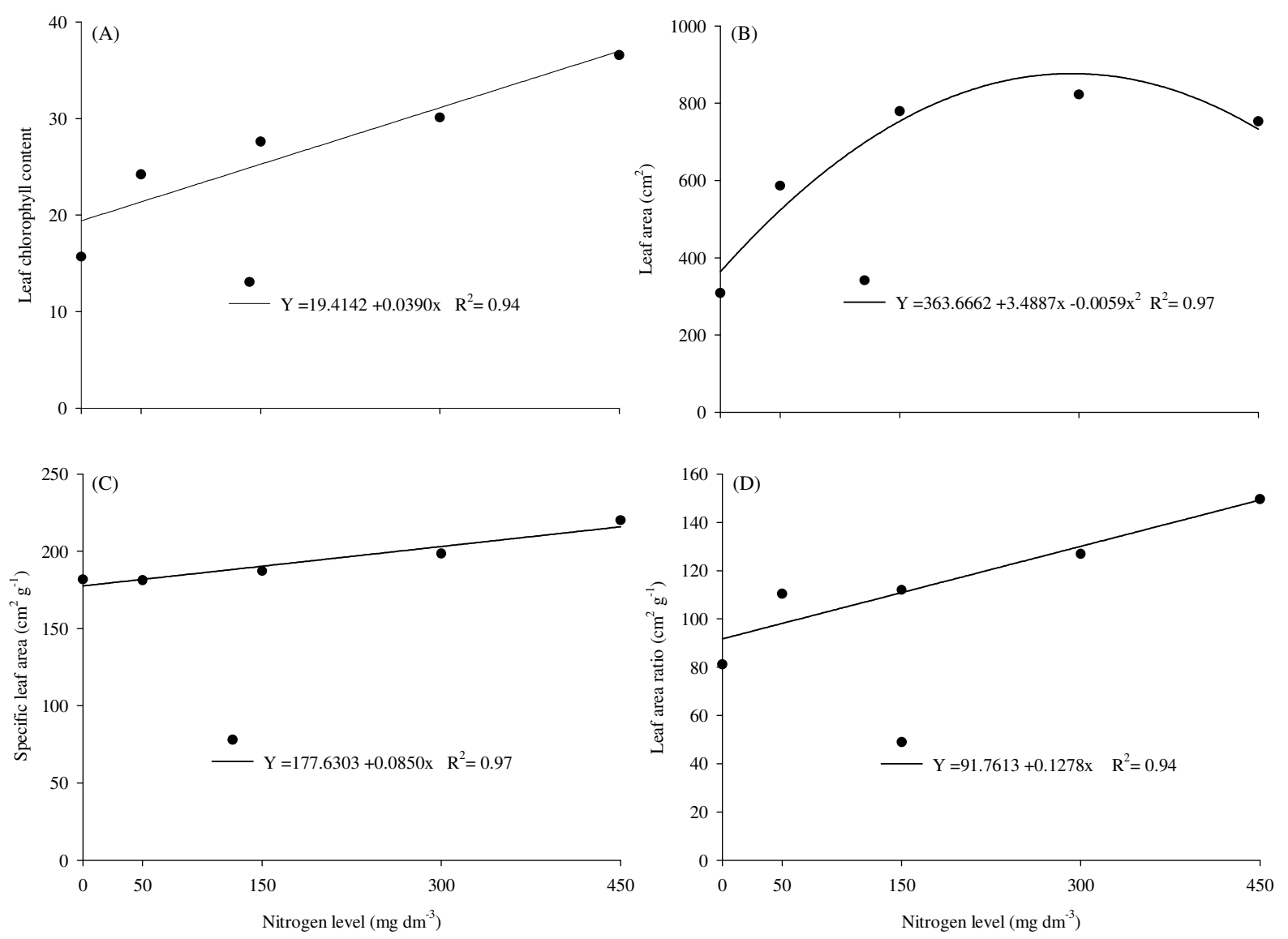

Figure 1. Leaf chlorophyll content (A), leaf area (B), specific leaf area (C) and leaf area ratio (D) of Handroanthus impetiginosus seedlings under mineral nitrogen fertilization. 
Chlorophyll plays an important role in photosynthesis by converting light energy to stored energy, and chlorophyll content in leaves is indirectly used to estimate plant nutrient status. This is because most leaf nitrogen is contained in chlorophyll molecules. Therefore, leaf chlorophyll content offers information on the nutritional and physiological status of seedlings (STEELE et al., 2008).

Another variable directly related to photosynthetic activity is leaf area. Considering that it represents the area of the main site for photosynthesis, leaf area can influence dry mass production and is an essential characteristic for assessment of seedling growth under fertilization (SOUZA et al., 2012). It is known that leaf size can be reduced by low nitrogen supply (MAFFEIS et al., 2000).

In the conditions of this study, leaf area of H. impetiginosus was best described by a quadratic model (Figure 1B). Seedlings fertilized with up to $300 \mathrm{mg} \mathrm{N} \mathrm{dm}^{-3}$ had a significant increase in leaf area. On the other hand, the use of higher nitrogen levels led to a drop in this variable, which may be a consequence of nutrient overdose.

For specific leaf area, an increasing linear response to the different nitrogen levels was found (Figure 1C). Thus, the specific leaf areas of seedlings fertilized with 50, 150, 300 and $450 \mathrm{mg} \mathrm{N}$ $\mathrm{dm}^{-3}$ were $2,7,14$ and $22 \%$ greater than those verified for non-fertilized seedlings, respectively.

Specific leaf area is defined as the ratio between leaf area and leaf dry mass, and specific leaf area is positively correlated with leaf nitrogen content and plant growth. Increasing specific leaf area is an effective way to expand leaf area with little energy expenditure for biomass production. This helps to improve the competitive ability of an individual (KNOPS; REINHART, 2000). As a result, seedlings with higher specific leaf area are able to absorb more light and grow more vigorously.

Similarly to specific leaf area, leaf area ratio is a useful tool for assessing plant growth. It constitutes the ratio between leaf area and total plant dry mass. Hence, the leaf area ratio expresses the leaf area that is used to produce $1 \mathrm{~g}$ of dry mass (POORTER; REMKES, 1990). The results obtained here show that the leaf area ratio of seedlings was also positive and linearly correlated with nitrogen levels. Nevertheless, this variable was more sensitive to nitrogen fertilization than the previous one, which can be noticed by the higher slope of the line that represents it (Figure 1D).

Dry mass accumulation has been considered one of the best parameters for evaluating seedling quality (BERNARDINO et al., 2005). Leaf and stem dry mass provides valuable information on seedling hardiness, whereas root dry mass has great influence on seedling survival rate and initial growth in the field (GOMES; PAIVA, 2004). Consequently, all of them contribute to successful establishment of seedlings in the field. Previous research has demonstrated that these variables usually have a quadratic response to nitrogen fertilization (CRUZ et al., 2006; TUCCI et al., 2009).

Root, stem, leaf and total dry mass of $H$. impetiginosus seedlings studied here also tended to respond quadratically to mineral nitrogen fertilization (Figure 2A). The maximum total dry mass was observed at around $240 \mathrm{mg} \mathrm{N} \mathrm{dm}^{-3}$ (calculated value). On average, this was the same nitrogen level required to maximize stem and leaf growth. However, root growth slightly decreased when nitrogen concentrations greater than $120 \mathrm{mg}$ $\mathrm{dm}^{-3}$ were used. This result is probably due to nitrogen overdose, which may lead to nutritional imbalance in the plant (SMARSI et al., 2011).

Nitrogen is an important component of amino acids, proteins, enzymes and other organic compounds (TAIZ; ZEIGER, 2010). Given that 50$70 \%$ of leaf nitrogen is contained in chloroplast enzymes (CHAPMAN; BARRETO, 1997), this nutrient is strictly essential for carbon assimilation. Hence, nitrogen fertilization promotes higher photosynthetic efficiency and leads to increased plant growth, as observed for seedlings fertilized with $240 \mathrm{mg} \mathrm{N} \mathrm{dm}^{-3}$.

The ratio between shoot dry mass and root dry mass of $H$. impetiginosus increased proportionally with the level of mineral nitrogen fertilization (Figure 2B). It was observed that nonfertilized seedlings produced $2.7 \mathrm{~g}$ of shoot dry mass for each $1.0 \mathrm{~g}$ of root dry mass. On the other hand, fertilized seedlings invested up to 2.3 times more in shoot growth than in root growth. This ratio is commonly used to express seedling quality. Nevertheless, its optimum value depends on the species as well as environmental factors (MARQUES et al., 2006).

The ratio between shoot height and shoot dry mass is of great importance to provide an estimate of seedling survival in the field (GOMES et al., 2003). The lower the value obtained from this ratio, the greater the seedling hardiness (BERNARDINO et al., 2005). 

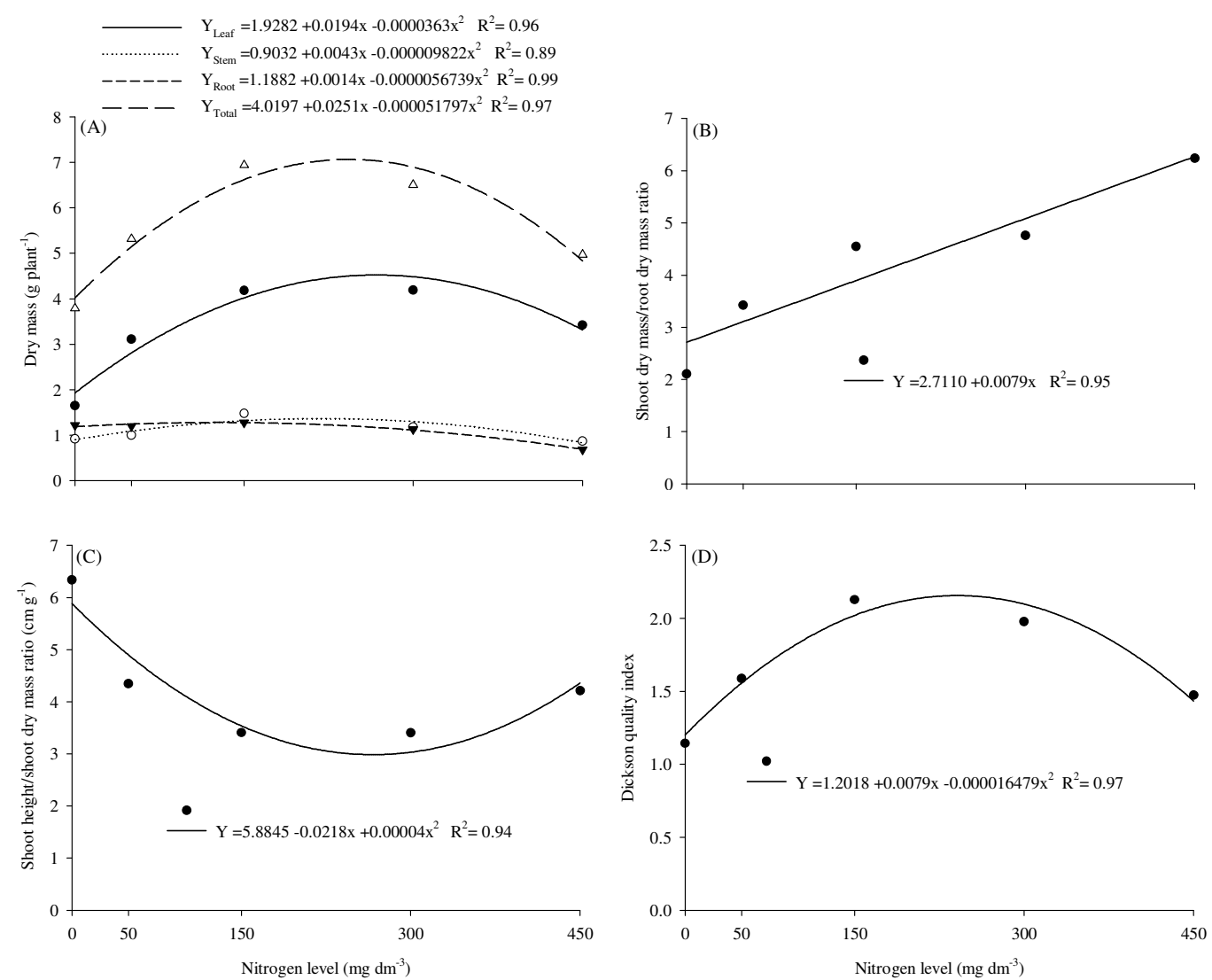

Figure 2. Root, stem, leaf and total dry mass (A), shoot dry mass/root dry mass ratio (B), shoot height/shoot dry mass ratio (C) and Dickson quality index (D) of Handroanthus impetiginosus seedlings under mineral nitrogen fertilization.

In general, good values were observed for this variable between 230 and $310 \mathrm{mg} \mathrm{N} \mathrm{dm}^{-3}$ (Figure 2C). Seedlings fertilized within these nitrogen levels had a shoot height/shoot dry mass ratio nearly $50 \%$ lower than those observed for nonfertilized seedlings. Consequently, they may perform better under field conditions (GOMES et al., 2003).

Another important indicator of seedling quality is the Dickson quality index, which takes into account seedling hardiness and balance of biomass distribution (GOMES et al., 2003; GOMES; PAIVA, 2004). The index assesses the ratio between morphological variables and is strongly correlated with dry mass production (BINOTTO et al., 2010; DICKSON et al., 1960).

Similarly to what was observed for total dry mass, the best Dickson quality index value for $H$. impetiginosus seedlings was achieved by fertilization with approximately $240 \mathrm{mg} \mathrm{N} \mathrm{dm}^{-3}$ (Figure 2D). As previously discussed for leaf area and root dry mass, the quadratic response may be indicative of nitrogen overdose (SMARSI et al., 2011). When in excess, this nutrient may lead to nutritional imbalance and compromise plant development. Accordingly, higher nitrogen levels should not be used, as they could reduce seedling growth and quality.

\section{CONCLUSIONS}

Mineral nitrogen fertilization improved seedling growth by promoting higher results of the leaf chlorophyll content, leaf area and shoot dry mass production. Thus, fertilized seedlings significantly expanded their leaves and invested more in shoot growth, improving their hardiness and quality.

The nitrogen level of $240 \mathrm{mg} \mathrm{dm}^{-3}$ was considered to be the most effective for production of Handroanthus impetiginosus seedlings.

RESUMO: O uso de espécies arbóreas nativas para restauração de áreas degradadas é muitas vezes prejudicada pela falta de informação sobre os requerimentos nutricionais de mudas na fase de viveiro. Portanto, este trabalho objetivou avaliar o crescimento e respostas morfológicas de mudas de ipê-roxo à adubação mineral nitrogenada. $\mathrm{O}$ experimento foi 
conduzido de julho a outubro de 2013, em viveiro de mudas com tela de sombreamento de $50 \%$. As sementes foram postas para germinar por 15 dias em bandejas de poliestireno de baixa densidade, e posteriormente transplantadas para sacos plásticos de polietileno de 0,9 L. Foi utilizado o delineamento de blocos completos ao acaso, com quatro repetições e quatro plantas por unidade experimental. Os tratamentos foram constituídos por cinco níveis de nitrogênio $(0,50,150,300$ e $450 \mathrm{mg} \mathrm{N} \mathrm{dm}^{-3}$ ), utilizando o sulfato de amônio como fonte. Dois meses após o transplantio, as seguintes variáveis foram avaliadas: conteúdo de clorofila foliar; área foliar; área foliar específica; razão de área foliar; matéria seca da raiz, caule, folhas e total; relação massa seca da parte aérea/massa seca da raiz; relação altura/massa seca da parte aérea; e índice de qualidade de Dickson. A adubação mineral nitrogenada otimizou o crescimento das mudas ao promover resultados mais elevados para o teor de clorofila, área foliar e produção de massa seca da parte aérea. Assim, mudas adubadas expandiram significativamente suas folhas e investiram mais no crescimento da parte aérea, melhorando sua rusticidade e qualidade. $\mathrm{O}$ nível de nitrogênio de $240 \mathrm{mg} \mathrm{dm}^{-3}$ foi considerado o mais eficiente para produção de mudas de ipê-roxo.

PALAVRAS-CHAVE: Handroanthus impetiginosus. Plantas nativas. Reflorestamento. Produção de mudas.

\section{REFERENCES}

BERNARDINO, D. C. S.; PAIVA, H. N.; NEVES, J. C. L.; GOMES, J. M.; MARQUES, V. B. Crescimento e qualidade de mudas de Anadenanthera macrocarpa (Benth.) Brenan em resposta à saturação por bases do substrato. Revista Árvore, Viçosa, v. 29, n. 6, p. 863-870, 2005. http://dx.doi.org/10.1590/S010067622005000600004

BINOTTO, A. F.; LÚCIO, A. D. C.; LOPES, S. J. Correlations between growth variables and the Dickson quality index in forest seedlings. Cerne, Lavras, v. 16, n. 4, p. 457-464, 2010. http://dx.doi.org/10.1590/S010477602010000400005

CALDEIRA, M. V. W.; ROSA, G. N.; FENILLI, T. A. B.; HARBS, R. M. P. Composto orgânico na produção de mudas de aroeira-vermelha. Scientia Agraria, Curitiba, v. 9, n. 1, p. 27-33, 2008.

http://dx.doi.org/10.5380/rsa.v9i1.9898

CECONI, D. E.; POLLETO, I.; LOVATO, T.; MUNIZ, M. F. B. Exigência nutricional de mudas de erva-mate (Ilex paraguariensis A. St.-Hil.) à adubação fosfatada. Ciência Florestal, Santa Maria, v. 17, n. 1, p. 25-32, 2007.

CHAPMAN, S. C.; BARRETO, H. J. Using a chlorophyll meter to estimate specific leaf nitrogen of tropical maize during vegetative growth. Agronomy Journal, Madison, v. 89, n. 4, p. 557-562, 1997. http://dx.doi.org/10.2134/agronj1997.00021962008900040004x

CRUZ, C. A. F.; PAIVA, H. N.; GUERRERO, C. R. A. Efeito da adubação nitrogenada na produção de mudas de sete-cascas (Samanea inopinata (Harms) Ducke). Revista Árvore, Viçosa, v. 30, n. 4, p. 537-546, 2006. http://dx.doi.org/10.1590/S0100-67622006000400006

DICKSON, A.; LEAF, A. L.; HOSNER, J. F. Quality appraisal of white spruce and white pine seedling stock in nurseries. Forest Chronicle, Mattawa, v. 36, n. 1, p. 10-13, 1960. http://dx.doi.org/10.5558/tfc36010-1

FERREIRA, D. F. Sisvar: a computer statistical analysis system. Ciência e Agrotecnologia, Lavras, v. 35, n. 6, p. 1039-1042, 2011.

GOMES, J. M.; PAIVA, H. P. Viveiros Florestais (propagação sexuada). 1 ed. Viçosa: UFV, 2004, 116 p.

GOMES, J. M.; COUTO, L.; LEITE, H. G.; XAVIER, A.; GARCIA, S. L. R. Crescimento de mudas de Eucalyptus grandis em diferentes tamanhos de tubetes e fertilização N-P-K. Revista Árvore, Viçosa, v. 27, n. 2, p. 113-127, 2003. http://dx.doi.org/10.1590/S0100-67622003000200001 
GONÇALVES, E. O.; PAIVA, H. N.; NEVES, J. C. L.; GOMES, J. M. Nutrição de mudas de angico-vermelho (Anadenanthera macrocarpa (Benth.) Brenan) submetidas a doses de N, P, K, Ca e Mg. Revista Árvore, Viçosa, MG, v.36, n.2, p. 219-228, 2012. http://dx.doi.org/10.1590/S0100-67622012000200003

KNOPS, J. M. H.; REINHART, K. Specific leaf area along a nitrogen fertilization gradient. The American Midland Naturalist, Notre Dame, v. 144, n. 2, p. 265-272, 2000. http://dx.doi.org/10.1674/00030031(2000)144[0265:SLAAAN]2.0.CO;2

MAIA, G. N. Caatinga: árvores e arbustos e suas utilidades. 1 ed. São Paulo: D\&Z computação gráfica e editora, 2004. $413 \mathrm{p}$.

MARQUES, V. B.; PAIVA, H. N.; GOMES, J. M.; NEVES, J. C. L.; BERNARDINO, D. C. S. Efeito de fontes e doses de nitrogênio sobre o crescimento inicial e qualidade de mudas de jacarandá-da-bahia (Dalbergia nigra (Vell.) Fr. All. ex Benth.). Revista Árvore, Viçosa, v. 30, n. 5, p. 725-735, 2006. http://dx.doi.org/10.1590/S0100-67622006000500006

MAFFEIS, A. R.; SILVEIRA, R. L. V. A.; BRITO, J. O. Reflexos das deficiências de macronutrientes e boro no crescimento de plantas, produção e qualidade de óleo essencial em Eucalyptus citriodora. Scientia Forestalis, Piracicaba, n. 57, v. 28, p. 87-98, 2000.

MALAVOLTA, E.; MORAIS, M. F. Fundamentos do nitrogênio e do nitrogênio e enxofre na nutrição de plantas cultivadas. In: YAMADA, T.; ABDALLA, S. R. S.; VITTI, G. C. (Ed.). Nitrogênio e enxofre na agricultura brasileira, Piracicaba: IPNI, 2007. p. 189-249.

POORTER, H.; REMKES, C. Leaf area ratio and net assimilation rate of 24 wild species differing in relative growth rate. Oecologia, v. 83, n. 4, p. 553-559, 1990. http://dx.doi.org/10.1007/BF00317209

SMARSI, R. C.; OLIVEIRA, G. F.; REIS, L. L.; CHAGAS, E. A.; PIO, R.; MENDONÇA, V.; CHAGAS, P. C.; CURI, P. N. Efeito da adubação nitrogenada na produção de mudas de lichieira. Revista Ceres, Viçosa, v. 58, n. 1, p. 129-131, 2011. http://dx.doi.org/10.1590/S0034-737X2011000100020

SOUSA, W. C.; NÓBREGA, R. S. A.; NÓBREGA, J. C. A.; BRITO, D. R. S.; MOREIRA, F. M. S. Fontes de nitrogênio e caule decomposto de Mauritia flexuosa na nodulação e crescimento de Enterolobium contortsiliquum. Revista Árvore, Viçosa, v. 37, n. 5, p. 969-979, 2013. http://dx.doi.org/10.1590/S010067622013000500019

SOUZA, M. S.; ALVES, S. S. V.; DOMBROSKI, J. L. D.; FREITAS, J. D. B.; AROUCHA, E. M. M. Comparação de métodos de mensuração de área foliar para a cultura da melancia. Pesquisa Agropecuária Tropical, Goiânia, v. 42, n. 2, p. 241-245, 2012. http://dx.doi.org/10.1590/S1983-40632012000200016

STEELE, M.; GITELSON, A. A.; RUNDQUIST, D. Nondestructive estimation of leaf chlorophyll content in grapes. American Journal of Enology and Viticulture, Davis, v. 59, n. 3, p. 299-305, 2008.

TAIZ, L.; ZEIGER, E. Plant physiology. 5 ed. Sunderland: Sinauer Associates, 2010, 782 p.

TUCCI, C. A. F., LIMA, H. N., LESSA, J. F. Adubação nitrogenada na produção de mudas de mogno (Swietenia macrophylla King). Acta Amazonica, Manaus, v. 39, n. 2, p. 289-294, 2009. http://dx.doi.org/10.1590/S0044-59672009000200007 